\title{
A Novel Ag-N-Heterocyclic Carbene Complex Bearing the Hydroxyethyl Ligand: Synthesis, Characterization, Crystal and Spectral Structures and Bioactivity Properties
}

\author{
Aydin Aktas ${ }^{1} \oplus$, Duygu Barut Celepci ${ }^{2}$, Yetkin Gok ${ }^{1}$, Parham Taslimi ${ }^{3}{ }^{\oplus}$, Hulya Akincioglu 4 \\ and İlhami Gulcin ${ }^{5, *(D)}$ \\ 1 Department of Chemistry, Faculty of Arts and Sciences, Inonu University, 44280-Malatya, Turkey; \\ aydinaktash@hotmail.com (A.A.); yetkin.gok@inonu.edu.tr (Y.G.) \\ 2 Department of Physics, Faculty of Science, Dokuz Eylul University, 35160-Buca, İzmir, Turkey; \\ duygu.barut@deu.edu.tr \\ 3 Department of Biotechnology, Faculty of Science, Bartin University, 74100-Bartin, Turkey; \\ parham_taslimi_un@yahoo.com \\ 4 Department of Chemistry, Faculty of Sciences and Arts, Agri Ibrahim Cecen University, 04100-Agri, Turkey; \\ hulyagocer84@gmail.com \\ 5 Department of Chemistry, Faculty of Sciences, Ataturk University, 25240-Erzurum, Turkey \\ * Correspondence: igulcin@atauni.edu.tr; Tel.: +90-442-231-4375
}

Received: 30 January 2020; Accepted: 1 March 2020; Published: 5 March 2020

\begin{abstract}
In this study, a novel silver N-heterocyclic carbene (Ag-NHC) complex bearing hydroxyethyl substituent has been synthesized from the hydroxyethyl-substituted benzimidazolium salt and silver oxide by using in-situ deprotonation method. A structure of the Ag-NHC complex was characterized by using UV-Vis, FTIR, ${ }^{1} \mathrm{H}-\mathrm{NMR}$ and ${ }^{13} \mathrm{C}-\mathrm{NMR}$ spectroscopies and elemental analysis techniques. Also, the crystal structure of the novel complex was determined by single-crystal X-ray diffraction method. In this paper, compound $\mathbf{1}$ showed excellent inhibitory effects against some metabolic enzymes. This complex had Ki of $1.140 .26 \mu \mathrm{M}$ against human carbonic anhydrase I (hCA I), $1.88 \pm 0.20 \mu \mathrm{M}$ against human carbonic anhydrase II (hCA I), and $10.75 \pm 2.47 \mu \mathrm{M}$ against $\alpha$-glycosidase, respectively. On the other hand, the Ki value was found as $25.32 \pm 3.76 \mu \mathrm{M}$ against acetylcholinesterase (AChE) and 41.31 $\pm 7.42 \mu \mathrm{M}$ against butyrylcholinesterase (BChE), respectively. These results showed that the complex had drug potency against some diseases related to using metabolic enzymes.
\end{abstract}

Keywords: N-heterocyclic carbene; crystal structure; enzyme inhibition; carbonic anhydrase; $\alpha$-glycosidase

\section{Introduction}

Medical applications of the silver metal were discovered a long time ago [1]. The most commonly used of silver compounds are silver nitrate and silver sulfonamides [2]. Today, most organisms have been known to develop antimicrobial resistance to drugs. Therefore, researchers have tried to develop novel, stronger and multimodal alternatives that have the least antibiotic effects on the human body [3]. At the clinical stage, silver has been shown to exhibit broad activity against antibiotics including those resistant to deadly microbes [4]. In recent studies, silver complexes exhibit less toxicity to the human body than other metal complexes, which have made them desirable antimicrobial substances [5].

The organic ligands, which coordinated to the silver metal center, make important contributions to biological activity. Among them, N-heterocyclic carbenes (NHCs) are one of the most important organic 
ligands. Transition metal complexes bearing NHC ligand have wide application areas. Biological activity applications of Ag-NHC complexes from these compounds have drawn attention. Furthermore, the biological activity applications of Ag-NHC complexes have started recently [2] and the number of studies on this subject is increasing day by day. In many studies, Ag-NHC complexes bearing functionalized NHC ligands exhibited promising biological activities [6,7]. In addition, the electronic and structural properties of NHCs and their modification properties have affected the biological activities of Ag-NHC complexes [8-11].

Carbonic anhydrases (CAs) are a structurally different enzyme family that catalyzes the interconversion of $\mathrm{CO}_{2}$ to $\mathrm{HCO}_{3}{ }^{-}$. This reaction influences physiological $\mathrm{pH}$ values and the supply of $\mathrm{HCO}_{3}{ }^{-}$ions and for plenty of metabolic, physiological, and biosynthetic pathways. The CA enzymes have a very active research area among medicinal chemists because designing CA inhibitors (CAIs) plays an important role in the therapy of some metabolic diseases including glaucoma, idiopathic intracranial hypertension, epilepsy, and altitude sickness [12-15].

The primary effect of AChE is the cancellation of nerve impulse conduction by the rapid hydrolysis of acetylcholine (ACh) in cholinergic synapses. Inhibition of this metabolic enzyme acts as a strategy for the duration of senile dementia, Parkinson's disease, ataxia, Alzheimer's disease (AD), myasthenia gravis and some disorders of autonomic nervous system functions. $\mathrm{BChE}$ is distinguished from $\mathrm{AChE}$ by its catalytic selectivity for butyrylcholine over acetylcholine hydrolysis. Looking at the points where they were synthesized, AChE is synthesized in muscle, nerve, and some hematopoietic cells. In excitable tissues, AChE is localized on the extracellular surface of both muscle and nerve and regulated by tissue-specific development. On the other hand, $\mathrm{BChE}$ is synthesized and released largely in the liver and is transported to the plasma. It is thought to play a primary role in the metabolism of dietary esters, perhaps only in selected species. Recently, a large spectrum of AChE inhibitors have been developed and approved to the treat $\mathrm{AD}$, such as donepezil, physostigmine, rivastigmine, huperzine- $\mathrm{A}$, galantamine and tacrine. These clinical drugs are capable to prevent the degradation of ACh and increase its level in the cholinergic synapses that can improve cognitive deficits. However, the adverse and undesired effects like nausea, vomiting and weight loss have limited their clinical usage and efficacy. So, it is necessary to develop novel cholinergic enzymes inhibitors with less toxic side effect and better therapeutic effect [16-18].

$\alpha$-Glycosidase is a digestion enzyme that hydrolyzes polysaccharides like disaccharides and starches to generate more metabolically available sugar units in the course of catabolic metabolism. Indeed, it can functionally hydrolyze carbohydrate molecules; the $\alpha$-glycosidase enzyme is distinct from $\beta$-glycosidase, which cleaves glycosides bonds. It is recorded that $\alpha$-glycosidase is associated with type-2 diabetes mellitus (T2DM) due to the fact that the high activity of this enzyme raised plasma glucose level and affects glucose absorption in these patients [19-22].

Recently, our work group investigated the enzyme inhibition activities of NHC precursors [23-26] and Pd(II)NHC complexes [27-30]. In this context, we synthesized a novel Ag-NHC complex and characterized its structure by using UV-Vis, FTIR, ${ }^{1} \mathrm{H}-\mathrm{NMR}$, and ${ }^{13} \mathrm{C}-\mathrm{NMR}$ spectroscopies and elemental analysis techniques. Further, we confirmed the structure of the novel Ag-NHC complex by using the single-crystal X-ray diffraction method. Finally, we investigated the inhibition effect of the novel Ag-NHC complex 1 against some metabolic enzymes.

\section{Materials and Methods}

The synthesis for the novel hydroxyethyl-liganded Ag-NHC complex 1 was prepared by using standard Schlenk techniques under an inert atmosphere. Any drying and purification weren't applied for all solvents purchased. All reagents were economically accessible by Merck and Sigma-Aldrich (Darmstadt, Germany), and abcr chemical Co (Karlsruhe, Germany). The starting benzimidazolium salt [28], which used in the synthesis of the novel Ag-NHC complex $\mathbf{1}$ was synthesized in Inonu University Organometallic Research Laboratory in Malatya, Turkey. The melting point was recognized in glass capillaries under air with an Electrothermal-9200 melting point apparatus (Giessen, Germany). 
Also, FTIR spectra assay were kept in the range $400-4000 \mathrm{~cm}^{-1}$ on Perkin Elmer Spectrum 100 FTIR spectrometer (Waltham, MA, USA). The UV spectrum was measured with Shimadzu UV-1601 instrument (Duisburg, Germany). The ${ }^{1} \mathrm{H}$ and ${ }^{13} \mathrm{C}$ NMR spectra were recorded using either a Bruker 400 Merkur spectrometer (Billerica, MA, USA) operating at ${ }^{1} \mathrm{H}$ NMR $(400 \mathrm{MHz})$ and ${ }^{13} \mathrm{C}$ NMR $(100 \mathrm{MHz})$ in DMSO- $\mathrm{d}_{6}$ with tetramethylsilane as an internal reference by Inonu University Catalysis Research and Application Center in Malatya, Turkey. Elemental analyses were performed by Inonu University Scientific and Technology Centre (Malatya, Turkey) on LECO, CNHS932 Elemental Analyzers (Haan, Germany).

\subsection{Synthesis of Ag-NHC Complex 1}

For the preparation of Ag-NHC complex 1; the 1-(2-hydroxyethyl)-3-ethylbenzimidazolium bromide $(0.379 \mathrm{~g}, 1.4 \mathrm{mmol})$ and silver(I)oxide $\left(\mathrm{Ag}_{2} \mathrm{O}\right)(0.162 \mathrm{~g}, 0.7 \mathrm{mmol})$ were reacted in dichloromethane $(30 \mathrm{~mL})$. To the reaction mixture were added activated molecular sieves (4 units). The mixture was stirred in dark for $48 \mathrm{~h}$. at room temperature. The mixture was filtered through celite ( $1 \mathrm{~cm}$ thick) and the solvent in the mixture was evaporated under vacuum. Then, the product was obtained as a white solid, which recrystallized from dichloromethane/ diethyl ether (1:3) at room temperature [31]. Yield: $80 \%$ (371 mg); m.p.: $158-159^{\circ} \mathrm{C} ; v\left(\mathrm{CN}\right.$ for 2-C): $1397 \mathrm{~cm}^{-1} ; v(\mathrm{OH}): 3157-3537$ $\mathrm{cm}^{-1}$. Anal. Calc. for $\mathrm{C}_{44} \mathrm{H}_{56} \mathrm{Ag}_{3} \mathrm{Br}_{3} \mathrm{~N}_{8} \mathrm{O}_{4}$ : C: $39.91 ; \mathrm{H}: 4.26$; N: 8.46. Found: C: 38.98, H: 4.02, $\mathrm{N}: 8.23 .{ }^{1} \mathrm{H}$ NMR $\left(400 \mathrm{MHz}, \mathrm{DMSO}_{6}\right) ; \delta 1.48\left(\mathrm{t}, 3 \mathrm{H}, \mathrm{J}=7.2 \mathrm{~Hz},-\mathrm{NCH}_{2} \mathrm{CH}_{3}\right) ; 3.87(\mathrm{t}, 2 \mathrm{H}, \mathrm{J}=5.2$ $\left.\mathrm{Hz},-\mathrm{NCH}_{2} \mathrm{CH}_{2} \mathrm{OH}\right) ; 4.53-4.59\left(\mathrm{~m}, 4 \mathrm{H},-\mathrm{NCH}_{2} \mathrm{CH}_{2} \mathrm{OH}\right.$ and $\left.-\mathrm{NCH}_{2} \mathrm{CH}_{3}\right) ; 5.12\left(\mathrm{~s}, 1 \mathrm{H},-\mathrm{NCH}_{2} \mathrm{CH}_{2} \mathrm{OH}\right)$; 7.42-7.83 (m, 4H, Ar-H). ${ }^{13} \mathrm{C}$ NMR (100 MHz, DMSO-d6); $\delta 16.5\left(-\mathrm{NCH}_{2} \mathrm{CH}_{3}\right) ; 44.2\left(-\mathrm{NCH}_{2} \mathrm{CH}_{3}\right) ; 51.7$ $\left(-\mathrm{NCH}_{2} \mathrm{CH}_{2} \mathrm{OH}\right) ; 60.9\left(-\mathrm{NCH}_{2} \mathrm{CH}_{2} \mathrm{OH}\right) ; 112.2,112.4,112.8,124.1,124.2,124.3,133.3,133.4$ and 134.4. (Ar-C); 190.0 (Ag- $\left.\mathrm{C}_{\text {carbene }}\right)$.

\subsection{Biochemical Studies}

The inhibiting effects of the Ag-NHC complex 1 on both carbonic anhydrase isoenzymes (hCA I and II) are described by Verpoorte et al. [32] and detailed in previous studies [33,34] and recorded spectrophotometrically using p-nitrophenylacetate substrate (PNA) at $348 \mathrm{~nm}[35,36]$. Indeed, the $\mathrm{BChE}$ and AChE inhibitory effects of Ag-NHC complex 1 were performed according to the Ellman's assay [37] and spectrophotometrically recorded at $412 \mathrm{~nm}$ [38]. Butyrylthiocholine iodide and acetylthiocholine iodide was substrates for both enzymatic reaction. On the other hand, 5,5'-dithio-bis (2-nitro-benzoic) acid molecule was used to measure $\mathrm{AChE}$ and $\mathrm{BChE}$ activities, respectively [39]. Additionally, the $\alpha$-glycosidase inhibitory effect of Ag-NHC complex 1 was carried out using the p-nitrophenyl-D-glycopyranoside molecule (p-NPG) as the substrate according to the method of Tao et al. [40] Samples of this work were prepared by dissolving as $\mathrm{mg} / \mathrm{mL}$. This assay was performed according to previous studies [41,42].

\subsection{X-ray Crystallography}

X-ray single crystal diffraction data for Ag-NHC complex $\mathbf{1}$ was collected at room temperature on a Rigaku-Oxford Xcalibur diffractometer (Oxford, UK) with an EOS-CCD detector using graphite-monochromatic MoK $\alpha$ radiation $(\lambda=0.71073 \AA$ ) with CrysAlisPro software (Oxford, UK) [43]. Data reduction and analytical absorption correction were performed by CrysAlisPro program [44]. Utilizing Olex2 [45], structure was solved using Intrinsic Phasing method with SHELXT [46] and refined by full-matrix least squares on F2 in SHELXL [47]. Anisotropic thermal parameters were applied to all non-hydrogen atoms. All hydrogen atoms were placed using standard geometric models and with their thermal parameters riding on those of their parent atoms. Some positional disorders were observed for hydroxyethyl groups in the structure, and to ensure satisfactory refinement of these disordered hydroxyethyl groups, constraint and restraint instructions such as EADP, DFIX, and DELU were applied. A summary of crystal data, experimental details, and refinement results for the Ag-NHC complex $\mathbf{1}$ is given in Table 1. Crystallographic data as cif file for the structure reported in this paper 
has been deposited at the Cambridge Crystallographic Data Center with CCDC 1979850 for complex 1. Copies of the data can be obtained free of charge at http:/www.ccdc.cam.ac.uk/conts/retrieving.html or from the Cambridge Crystallographic Data Center, 12, Union Road, Cambridge CB2 1EZ, UK. Fax: (+44) 1223-336-033, email: deposit@ccdc.cam.ac.uk.

Table 1. Crystal data and experimental details for the Ag-NHC complex 1.

\begin{tabular}{ll}
\hline \multicolumn{1}{c}{ Crystal Data } & \multicolumn{1}{c}{ Experimental Details } \\
\hline Empirical Formula & $\mathrm{C}_{44} \mathrm{H}_{56} \mathrm{Ag}_{3} \mathrm{Br}_{3} \mathrm{~N}_{8} \mathrm{O}_{4}$ \\
Formula Weight & 1324.30 \\
Temperature $(\mathrm{K})$ & $293(2)$ \\
Crystal System, space group & Monoclinic, $P 2_{1} / n$ \\
$a, b, c(\AA)$ & $10.7530(6), 13.2516(10), 17.8818(11)$ \\
$\alpha, \beta, \gamma\left({ }^{0}\right)$ & $90,106.473(6), 90$ \\
$V\left(\AA^{3}\right)$ & $2443.5(3)$ \\
$Z$ & 2 \\
Density (calculated) $\left(\mathrm{g} / \mathrm{cm}^{3}\right)$ & 1.800 \\
Absorption coefficient $\left(\mu, \mathrm{mm}^{-1}\right)$ & 3.692 \\
$F(000)$ & 1308 \\
Crystal size (mm $\left.{ }^{3}\right)$ & $0.386 \times 0.342 \times 0.178$ \\
Radiation & MoK $\alpha(\lambda=0.71073)$ \\
$2 \theta$ range for data collection $\left(^{\circ}\right)$ & 6.002 to 51.358 \\
Index ranges & $-6 \leq \mathrm{h} \leq 13,-16 \leq \mathrm{k} \leq 7,-21 \leq 1 \leq 21$ \\
Reflections collected & 8043 \\
Independent reflections & $4589\left[\mathrm{R}_{\text {int }}=0.027, \mathrm{R}_{\text {sigma }}=0.055\right]$ \\
Restraints/Parameters & $8 / 269$ \\
Goodness-of-fit on $F^{2}$ & 1.034 \\
Final $R$ indices $[I \geq 2 \sigma(I)]$ & $R_{1}=0.074, w R_{2}=0.208$ \\
$R$ indices & $R_{1}=0.113, w R_{2}=0.237$ \\
\hline
\end{tabular}

\section{Results and Discussion}

\subsection{Synthesis}

The Ag-NHC complex 1 bearing hydroxyethyl-liganded have illustrated in Scheme 1. The complex was synthesized from the hydroxyethyl-substituted benzimidazolium salt [28] and silver oxide via in-situ deprotonation method. The reaction mixture was stirred in dark during $48 \mathrm{~h}$. at room temperature. The Ag-NHC complex 1 was obtained as a white solid at $80 \%$ yield. The novel stable complex was well soluble in halogenated solvents such as dichloromethane and chloroform. Also, the Ag-NHC complex 1 was well soluble in polar solvents such as dimethylsulfoxide and dimethylformamide. But, this complex was less soluble in polar solvents such as water and ethanol.

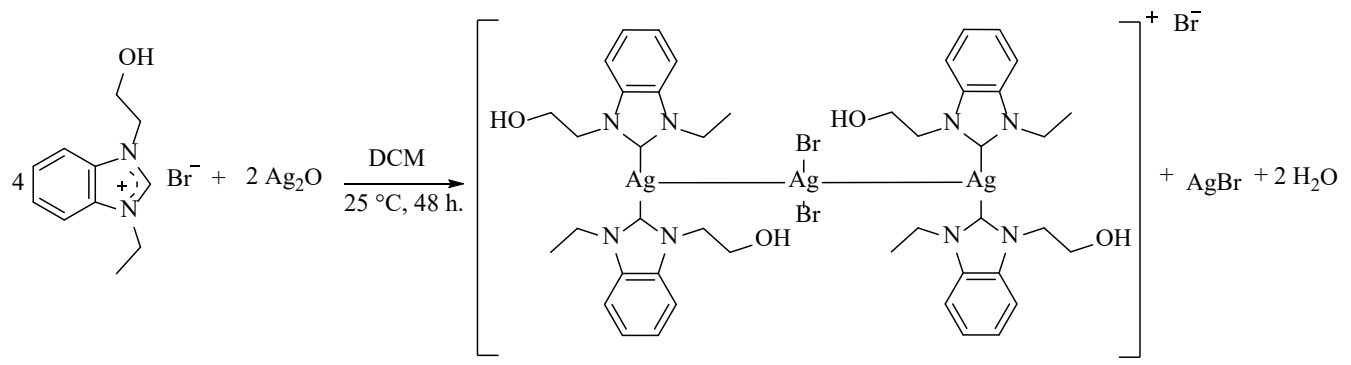

Scheme 1. Synthesis of the hydroxyethyl-substituted Ag-NHC complex 1.

\subsection{NMR Study}

The structure of the Ag-NHC complex 1 was characterized by ${ }^{1} \mathrm{H}$ NMR and ${ }^{13} \mathrm{C}$ NMR spectroscopic methods. When the ${ }^{1} \mathrm{H}$ NMR data was examined, the characteristic proton peak that observed at 
$10.42 \mathrm{ppm}$ for the starting benzimidazolium salt [28] was not observed in the novel Ag-NHC complex. The $-\mathrm{CH}_{3}$ and $-\mathrm{CH}_{2}$ proton peaks belonging to the ethyl group $\left(-\mathrm{NCH}_{2} \mathrm{CH}_{3}\right)$ have been observed as triplets at $1.48 \mathrm{ppm}(\mathrm{J}=7.2 \mathrm{~Hz})$ and as multiplets at $4.55 \mathrm{ppm}$, respectively. The two $-\mathrm{CH}_{2}$ proton peaks belonging to the hydroxyethyl group $\left(-\mathrm{NCH}_{2} \mathrm{CH}_{2} \mathrm{OH}\right)$ have been observed as triplet at $3.87 \mathrm{ppm}$ $(\mathrm{J}=5.2 \mathrm{~Hz})$ and as multiplets at $4.58 \mathrm{ppm}$ respectively. The broad (wide) singlet peak was observed at $5.12 \mathrm{ppm}$ for hydroxy proton in the ${ }^{1} \mathrm{H}$ NMR spectrum. The aromatic proton peaks of benzimidazole have observed as multiplited between 7.42 and $7.83 \mathrm{ppm}$. When the ${ }^{13} \mathrm{C}$ NMR data was examined, the characteristic carbon peak that observed at $141.7 \mathrm{ppm}$ for the 2- $\mathrm{CH}$ of the starting benzimidazolium salt [28] was not observed in the novel Ag-NHC complex. Furthermore, the characteristic $\mathrm{Ag}-\mathrm{C}_{\text {carbene }}$ resonance for the novel Ag-NHC complex 1 was observed in the ${ }^{13} \mathrm{C}$ NMR spectra appeared highly downfield at $190.0 \mathrm{ppm}$. The $-\mathrm{CH}_{2}$ aliphatic carbon atom bonding to -OH on the hydroxyethyl group has been observed at $60.9 \mathrm{ppm}$. The $-\mathrm{CH}_{2}$ aliphatic carbon atom bonding to the nitrogen on the hydroxyethyl group $\left(-\mathrm{NCH}_{2} \mathrm{CH}_{2} \mathrm{OH}\right)$ has been observed at $51.7 \mathrm{ppm}$. The $-\mathrm{CH}_{3}$ and $-\mathrm{CH}_{2}$ aliphatic carbon peaks belonging to the ethyl group $\left(-\mathrm{NCH}_{2} \mathrm{CH}_{3}\right)$ have been observed at 16.5 and $44.2 \mathrm{ppm}$ respectively. The aromatic carbon peaks of benzimidazole observed between 112.2 and $134.4 \mathrm{ppm}$. All ${ }^{1} \mathrm{H}$ NMR data (Figure 1) and ${ }^{13} \mathrm{C}$ NMR data (Figure 2) for the novel Ag-NHC complex $\mathbf{1}$ have compatible with the literature $[6,7]$.

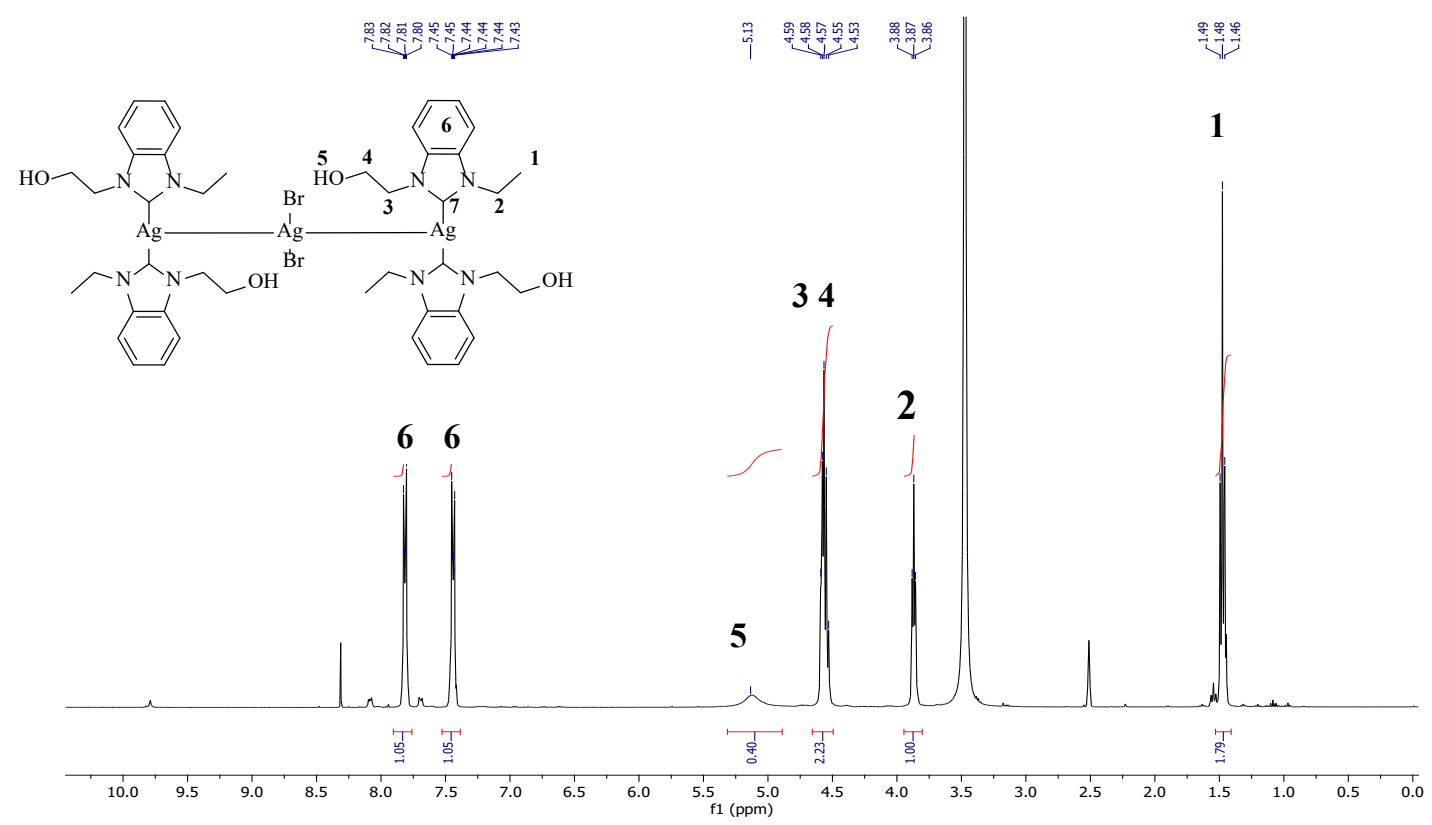

Figure 1. The ${ }^{1} \mathrm{H}$ NMR data for the hydroxyethyl-substituted Ag-NHC complex 1.

\subsection{FTIR Study}

Herein, the FTIR spectroscopy has been used to describe the functional groups available in the complex. The FTIR spectrum of the novel Ag-NHC complex $\mathbf{1}$ has illustrated in Figure 3. It has been recorded for the wavenumbers region between 4000 and $450 \mathrm{~cm}^{-1}$. When the investigation of the FTIR spectrum, the symmetrical $\mathrm{C}-\mathrm{H}$ stretching frequency of the benzene rings observed intense at 3119 and $3155 \mathrm{~cm}^{-1}$. The symmetrical $\mathrm{C}-\mathrm{H}$ stretching frequency of the $-\mathrm{CH}_{2}-$ and $-\mathrm{CH}_{3}$ groups in the ethyl and the $-\mathrm{CH}_{2}$ - groups in the hydroxyethyl becomes intense at 2869,2934 and $2975 \mathrm{~cm}^{-1}$. The symmetrical $C=C-C$ stretching frequency of the benzene rings become intense at $1555 \mathrm{~cm}^{-1}$. The symmetrical conjugated $\mathrm{C}=\mathrm{C}$ bond stretching frequency of the benzene rings becomes intense at 1344 $\mathrm{cm}^{-1}$. The band at $1039 \mathrm{~cm}^{-1}$ and $1054 \mathrm{~cm}^{-1}$ corresponds to the primary alcohol (hydroxyethyl group) $\mathrm{C}-\mathrm{O}$ stretching mode. The band at $1288 \mathrm{~cm}^{-1}$ corresponds to the primary alcohol (hydroxyethyl group) $\mathrm{O}-\mathrm{H}$ in-plane bending vibration. The symmetrical for $\mathrm{C}_{\text {carbene }}-\mathrm{N}$ stretching frequency in the 
benzimidazole group observed intense at $1397 \mathrm{~cm}^{-1}$ [48,49]. According to the literature, $\mathrm{Ag}-\mathrm{C}$ stress vibrations are expected in the frequency region of $400-155 \mathrm{~cm}^{-1}$ [50].
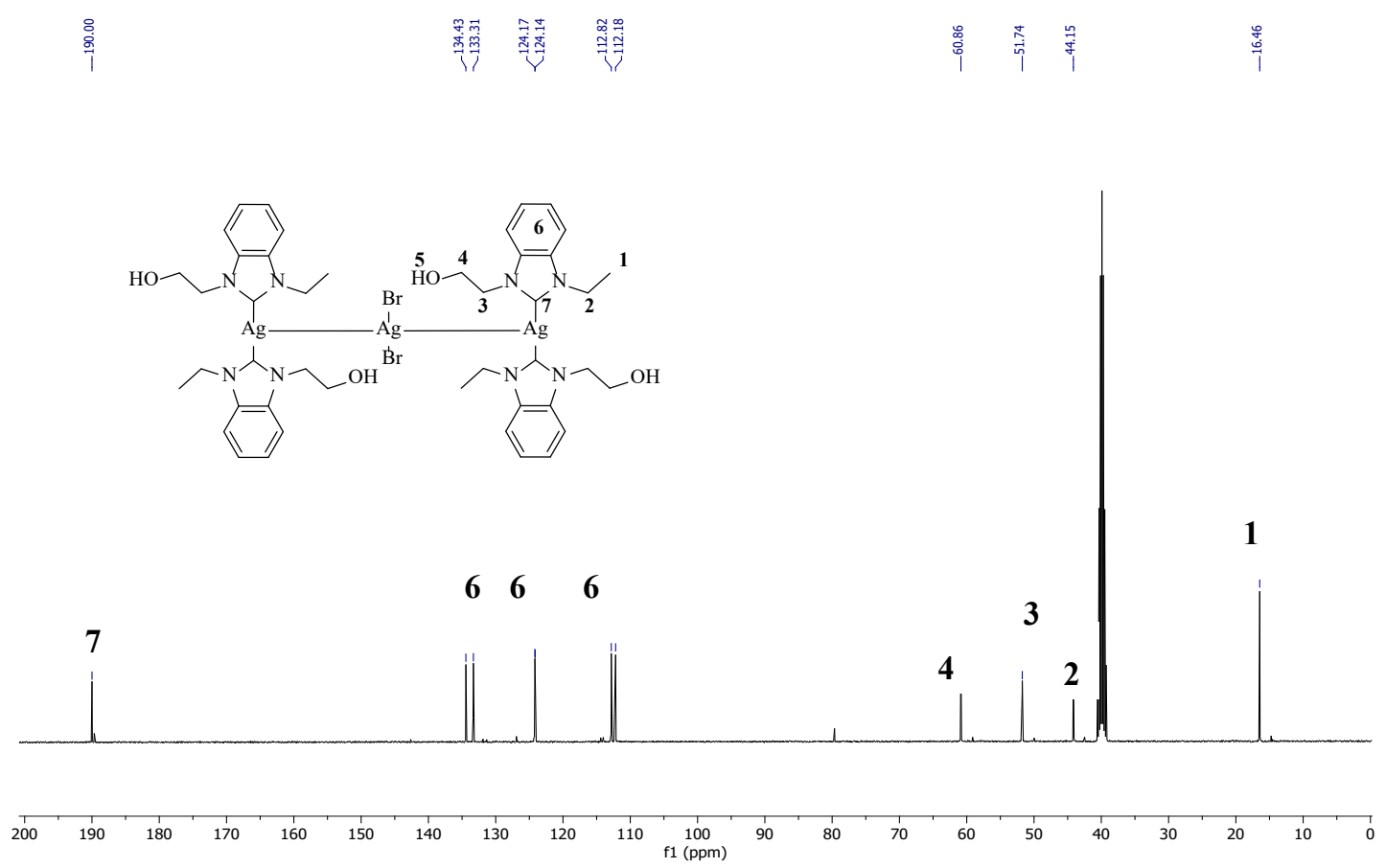

Figure 2. The ${ }^{13} \mathrm{C}$ NMR data for the hydroxyethyl-substituted Ag-NHC complex 1.

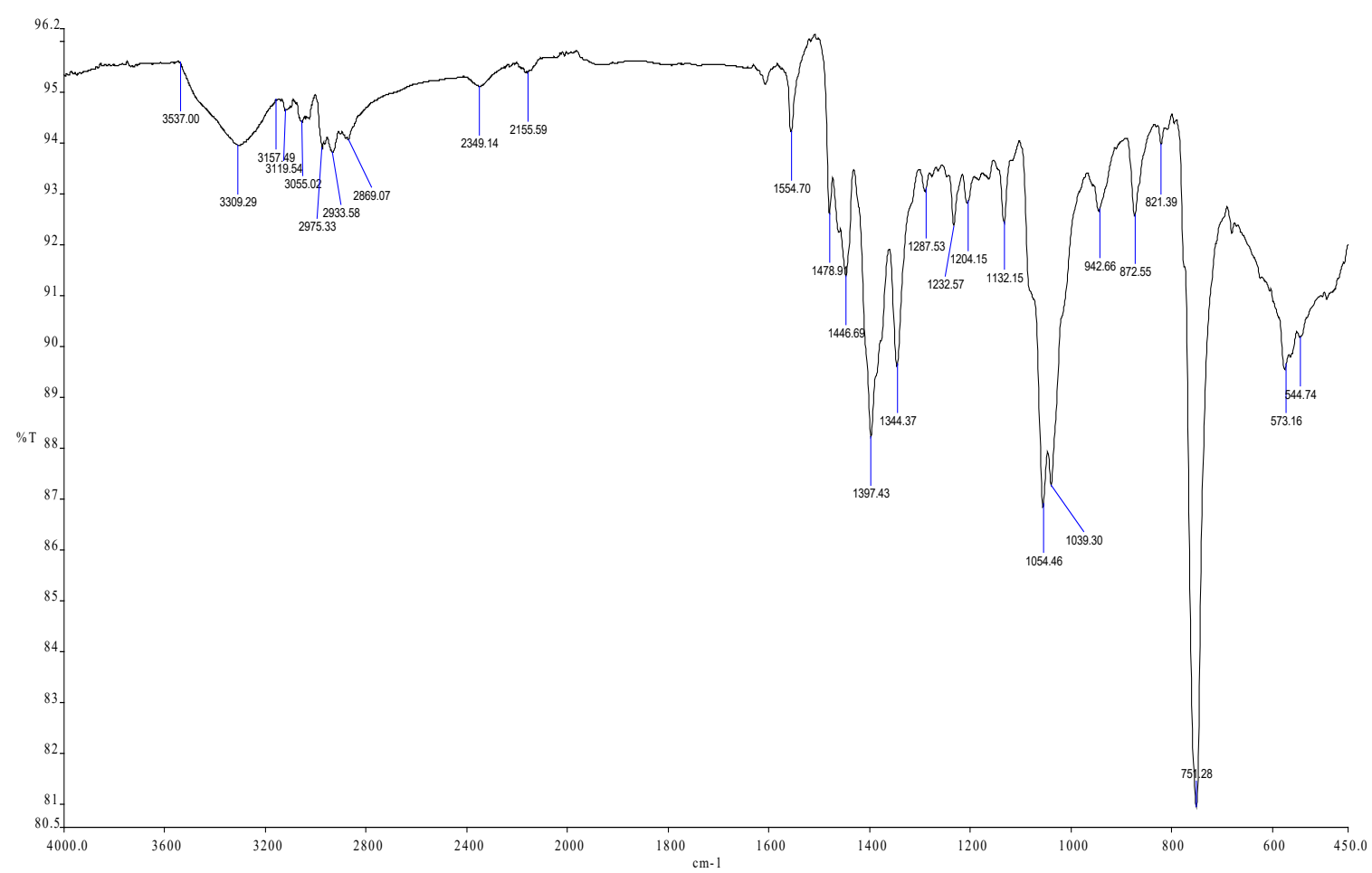

Figure 3. The FTIR spectrum of the hydroxyethyl-substituted Ag-NHC complex $\mathbf{1}$.

\subsection{UV-Vis Study}

The UV-Vis spectra of the novel Ag-NHC complex of dissolved in chloroform at $25^{\circ} \mathrm{C}$ showed up four absorption bands at 220, 250, 270 and $320 \mathrm{~nm}$, respectively. The UV-Vis spectra of the novel Ag-NHC complex 1 were recorded in $\left(\mathrm{CHCl}_{3}\right)$ solutions at a concentration of 15 or $10 \mu \mathrm{M}$ and were 
depicted in Figure 4 with a range 200 400 nm. The novel Ag-NHC complex 1 showed a new absorption peak at 320 related to MLCT (metal-ligand charge transfer) $\left(\mathrm{Ag}^{+}\right.$to NHC ligand) (Figure 4) [51]. This peak is known as the wide range bands, both $\pi \rightarrow \pi^{*}, \mathrm{n} \rightarrow \pi^{*}$ and d-d transitions of $(C=N)$ and charge-transfer transition arising from $\pi$ electron interactions between metal and ligand that involves either a metal-to-ligand or ligand-to-metal electron transfer [52]. The absorption bands below 220 270 $\mathrm{nm}$ in $\mathrm{CHCl}_{3}$ are practically identical and can be attributed to $\pi \rightarrow \pi^{*}$ transitions in the benzene and benzimidazole ring $[51,53]$.

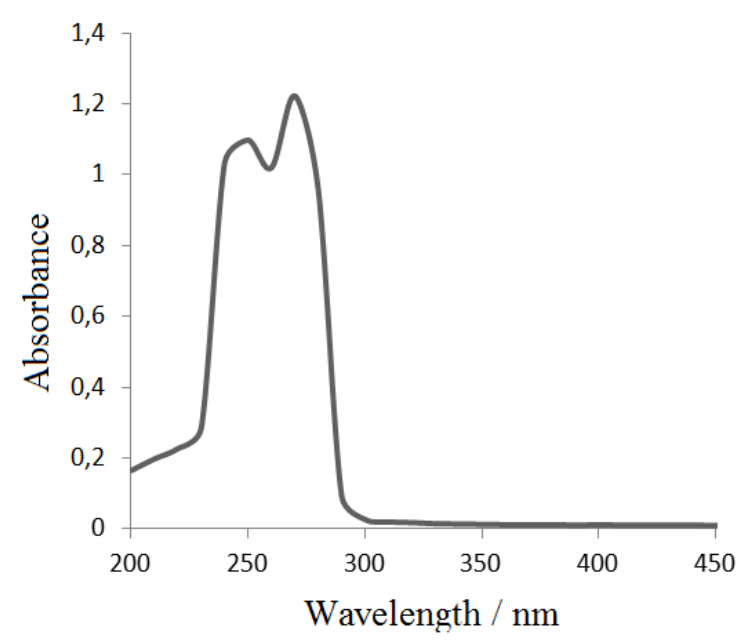

Figure 4. The UV-Vis spectrum of the hydroxyethyl-substituted Ag-NHC complex 1.

\subsection{Description of the Crystal Structure of Ag-NHC Complex 1}

A molecular representation of the Ag-NHC complex 1 is depicted in Figure 5. The asymmetric unit of the Ag-NHC complex 1 contains a half of molecule and completed with Ci symmetry operation. The coordination environment comprises of a nearly linear $\left[\mathrm{Ag}(\mathrm{NHC})_{2}\right]^{+}$cation and a $[\mathrm{AgBr}]$-anion with an almost perpendicular orientation to the cation $\left[\mathrm{C} 1-\mathrm{Ag} 1-\mathrm{Ag} 2-\mathrm{Br} 1=90.2(2)^{\circ}, \mathrm{C} 12-\mathrm{Ag} 1-\mathrm{Ag} 2-\mathrm{Br} 1\right.$ $\left.=-87.8(2)^{\circ}\right]$. There is also a bromide ion in the asymmetric unit, connected to the cation molecule with a hydrogen bond. The angle $\mathrm{C} 1-\mathrm{Ag} 1-\mathrm{C} 12$ is $171.1(3)^{\circ}$ and deviates from the linear geometry. The Ag1 ... Ag2 association is 3.097(6) $\AA$, is almost low comparing the Ag ... Ag bond distances in the literature [54]. The cationic $\mathrm{Ag}-\mathrm{C}$ bond distances are consistent with the similar $\mathrm{Ag}(\mathrm{NHC})$ complexes

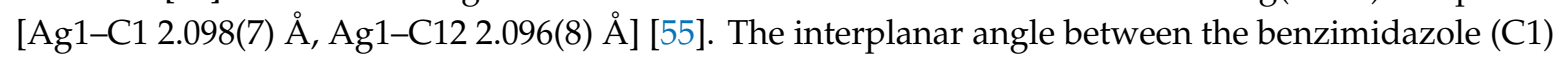
ring and the $\mathrm{C} 1-\mathrm{Ag} 1-\mathrm{Ag} 2$ plane is $79.50(16)^{\circ}$ and that between benzimidazole (C12) ring and the C12-Ag1-Ag2 plane is 76.95(17) .

In the crystal packing of the complex 1 , cation molecules linked to each other via bromide anions with $\mathrm{O} 1-\mathrm{H} 1 \cdots \mathrm{Br} 2 \mathrm{i}\left[\mathrm{H} 1 \cdots \mathrm{Br} 2=2.58 \AA, \mathrm{O} 1-\mathrm{Br} 2=3.15(3) \AA, \mathrm{O} 1-\mathrm{H} 1 \cdots \mathrm{Br} 2=127^{\circ}\right.$, symmetry code: $\mathrm{i} 3 / 2-$ $\mathrm{x},-1 / 2+\mathrm{y}, 3 / 2-\mathrm{z}]$; O2A-H2AA $\cdots \mathrm{Br} 2[\mathrm{H} 2 \mathrm{AA} \cdots \mathrm{Br} 2=2.25 \AA, \mathrm{O} 2 \mathrm{~A}-\mathrm{Br} 2=3.04(2) \AA, \mathrm{O} 2 \mathrm{~A}-\mathrm{H} 2 \mathrm{AA} \cdots \mathrm{Br} 2$ $\left.=163^{\circ}\right]$ and $\mathrm{O} 2 \mathrm{~B}-\mathrm{H} 2 \mathrm{BA} \cdots \mathrm{Br} 2\left[\mathrm{H} 2 \mathrm{BA} \cdots \mathrm{Br} 2=2.17 \AA, \mathrm{O} 2 \mathrm{~B}-\mathrm{Br} 2=2.89(3) \AA, \mathrm{O} 2 \mathrm{~B}-\mathrm{H} 2 \mathrm{BA} \cdots \mathrm{Br} 2=147^{\circ}\right]$ hydrogen bonding interactions forming an infinite chain along the $b$ - and c-axis. The crystal structure is also stabilized by $\mathrm{C}-\mathrm{H} \cdots \mathrm{Br}$ and $\mathrm{C}-\mathrm{H} \cdots \mathrm{O}$ type intra- and intermolecular weak interactions. As can be seen in Figure 6, the Ag2 atoms settle in each corner of the unit cell and one is in the middle of the unit cell, while the bromide anions are between these corners Ag2 atoms. 


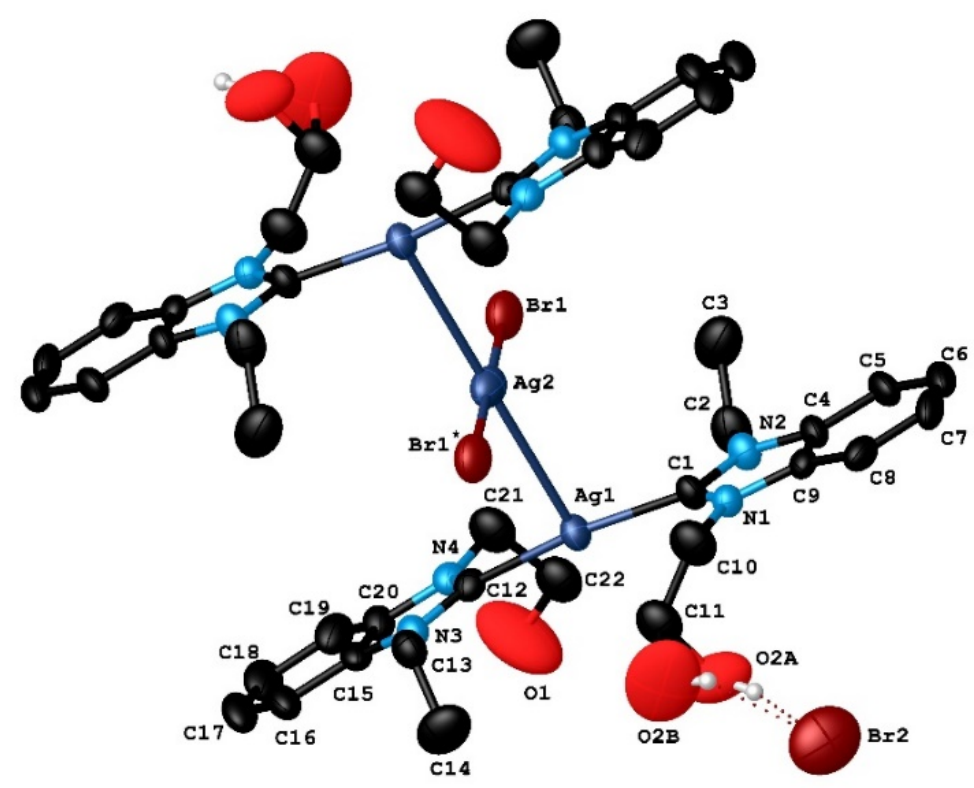

Figure 5. Molecular structure of Ag-NHC complex 1 with ellipsoids drawn at 30\% probability level. Selected bond lengths $(\AA)$ and angles $\left(^{\circ}\right)$ : Ag1-Ag2 3.0966(7), Ag1-C1 2.098(7), Ag1-C12 2.096(8), Ag2-Br1 2.4277(14); Ag1-Ag2-Br1 86.39(3), C1-Ag1-C12 171.1(3), C1-Ag1-Ag2 93.0(2), C12-Ag1-Ag2 95.6(2), C1-N1-C10 125.4(7), N1-C10-C11 115.5(9), C1-N2-C2 125.3(7), N2-C2-C3 111.9(10), C10-C11-O2A 112.6(14), C10-C11-O2B 116.2(17), C12-N3-C13 124.6(7), N3-C13-C14 112.9(8), C12-N4-C21 125.2(8), N4-C21-C22 111.0(9), C21-C22-O1 107.3(14). [Symmetry code: $\left(^{*}\right) 1-\mathrm{x}, 1-\mathrm{y}, 1-\mathrm{z}$ ].

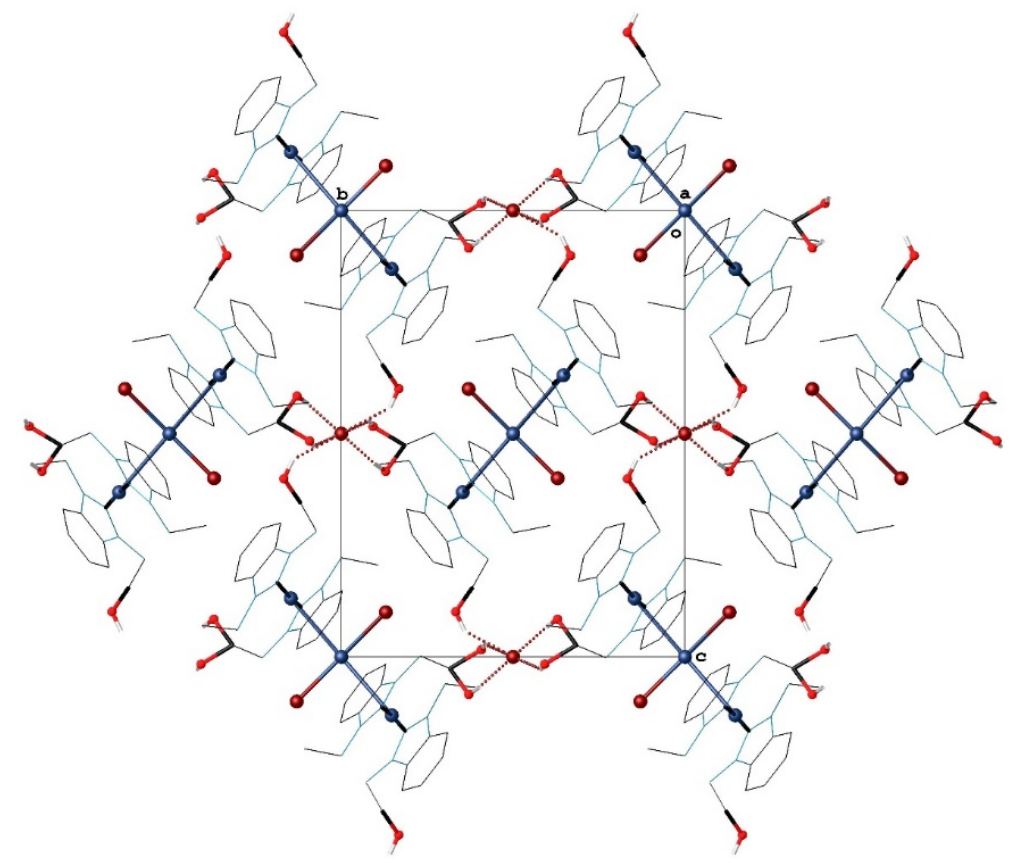

Figure 6. Representation of the packing diagram for the Ag-NHC complex 1. The Ag2 atoms settle in each corner of the unit cell and one is in the middle, while the bromide anions are between these corner silver atoms. The $\mathrm{Ag}, \mathrm{Br}$ and $\mathrm{O}$ atoms are shown as balls, while the other atoms are shown in a wireframe style. For the sake of clarity, hydrogen atoms that do not to play role in the bonding are omitted. 


\subsection{Enzyme Inhibition Studies}

Inhibitors of metabolic enzymes can constitute new therapeutics against cancer or may have potential as antibacterial and antifungal drugs [56,57]. Recently, the inhibition of human CAs by sulfonamide compounds has been recorded to inhibit the growth of pathogenic microorganisms. Selective inhibition of CA II constitutes a viable approach to fight against the disturbances caused by the harmful effects of CA II enzyme [58-60]. When testing the results, the following inhibition activity relevance could be considered and summarized:

1. For the hCA I isoenzyme, Ag-NHC complex $\mathbf{1}$ had $\mathrm{K}_{\mathrm{i}}$ and $\mathrm{IC}_{50}$ values of $1.14 \pm 0.26$ and $0.93 \mu \mathrm{M}$, respectively (Table 2). Additionally, for the hCA II isoform, Ag-NHC complex $\mathbf{1}$ had $\mathrm{Ki}$ and $\mathrm{IC}_{50}$ values $1.88 \pm 0.20$ and $1.26 \mathrm{nM}$, respectively (Table 2). In this work, acetazolamide (AZA) as a positive CA inhibitor, which used for therapy of epileptic seizure, altitude sickness, glaucoma, dural ectasia, and idiopathic intracranial hypertension, had $\mathrm{IC}_{50}$ values of 54.88 and $48.22 \mu \mathrm{M}$ for hCA I, and hCA II. Also, AZA showed $\mathrm{K}_{\mathrm{i}}$ values of $50.17 \pm 4.17$ and $42.15 \pm 8.11 \mu \mathrm{M}$ against both isoenzymes, respectively (Table 2). $\mathrm{IC}_{50}$ values of Ag-NHC complex 1 and AZA exhibited the following order: Ag-NHC complex $1\left(0.9300, \mathrm{r}^{2}: 0.9786 \mu \mathrm{M}\right)<\mathrm{AZA}\left(54.88, \mathrm{r}^{2}: 0.9880 \mu \mathrm{M}\right)$ for hCA I while these compound exhibited for hCA II the following order: Ag-NHC complex 1 (1.26 $\left.\mu \mathrm{M}, \mathrm{r}^{2}: 0.9435 \mu \mathrm{M}\right)<\mathrm{AZA}\left(48.22 \mathrm{nM}, \mathrm{r}^{2}: 0.9878 \mu \mathrm{M}\right)$.

2. There are multiple synthetical drugs like tacrine, donepezil, and rivastigmine based on for the duration of cognitive dysfunction and memory loss related to AD. These components have been reported to have side effects such as gastrointestinal disorders related to biocompatibility issues [61-63]. Ag-NHC complex 1 effectively inhibited both cholinergic BChE and AChE enzymes. It was obtained that $\mathrm{K}_{\mathrm{i}}$ values were $25.32 \pm 3.76 \mu \mathrm{M}$ for AChE and $41.31 \pm 7.42 \mu \mathrm{M}$ for $\mathrm{BChE}$, respectively (Table 2). In addition, Tacrine (TAC) was used as positive control BChE and AChE inhibitor it had $K_{i}$ values $47.18 \pm 8.37$ and $69.08 \pm 13.40 \mu \mathrm{M}$, respectively. $\mathrm{IC}_{50}$ values of Ag-NHC complex 1 and Tacrine exhibited the following order: Ag-NHC complex $1\left(36.41 \mu \mathrm{M}, \mathrm{r}^{2}\right.$ : $0.9745)<$ Tacrine $\left(76.20 \mu \mathrm{M}, \mathrm{r}^{2}: 0.9874\right)$ for AChE while these compound exhibited for BChE the following order: Ag-NHC complex $1\left(50.25 \mu \mathrm{M}, \mathrm{r}^{2}: 0.9790\right)<$ Tacrine $\left(96.40 \mu \mathrm{M}, \mathrm{r}^{2}: 0.9424\right)$.

3. The $\alpha$-glycosidase inhibitors as oral antidiabetic compounds, which inhibit upper gastrointestinal enzymes that break down the carbohydrate polysaccharides into glucose units. Indeed, the absorption of glucose is delayed postprandial glucose levels [64-67]. For glycosidase, Ag-NHC complex 1 and acarbose have $\mathrm{IC}_{50}$ values of $8.11\left(\mathrm{r}^{2}: 0.9252\right)$ and $22.80 \mu \mathrm{M}$, respectively. Their $\mathrm{K}_{\mathrm{i}}$ values were found as $10.75 \pm 2.47$ and $12.60 \pm 0.70 \mu \mathrm{M}$, respectively. (Table 2). The results have clearly documented that Ag-NHC complex 1 had shown effective inhibitory effects against $\alpha$-glycosidase inhibition than that of acarbose $\left(\mathrm{IC}_{50}: 22.80 \mu \mathrm{M}\right)$ as a standard $\alpha$-glycosidase inhibitor [40]. IC 50 values of Ag-NHC complex $\mathbf{1}$ and acarbose exhibited the following order: Ag-NHC complex $1\left(8.11 \mu \mathrm{M}, \mathrm{r}^{2}: 0.9252\right)<$ Acarbose for $\alpha$-glycosidase $[68,69]$. 
Table 2. The enzyme inhibition results ( $\mathrm{IC}_{50}$ and $\mathrm{K}_{\mathrm{i}}$ values) of Ag-NHC complex 1 against hCA I, hCA II, $\alpha$-Glycosidase, AChE, and BChE enzymes.

\begin{tabular}{|c|c|c|c|c|c|c|c|c|c|c|c|c|c|c|c|}
\hline \multirow{2}{*}{ Compounds } & \multicolumn{10}{|c|}{$\mathrm{IC}_{50}(\mu \mathrm{M})$} & \multicolumn{5}{|c|}{$\mathbf{K}_{\mathbf{i}}(\mu \mathrm{M})$} \\
\hline & hCA I & $\mathrm{r}^{2}$ & hCA II & $\mathrm{r}^{2}$ & AChE & $r^{2}$ & BChE & $\mathrm{r}^{2}$ & $\alpha$-Gly & $\mathrm{r}^{2}$ & hCA I & hCA II & AChE & BChE & $\alpha$-Gly \\
\hline Complex 1 & 0.93 & 0.9786 & 1.26 & 0.9435 & 36.41 & 0.9745 & 50.25 & 0.9790 & 8.11 & 0.9252 & $1.14 \pm 0.26$ & $1.88 \pm 0.20$ & $25.32 \pm 3.76$ & $41.31 \pm 7.42$ & $10.75 \pm 2.47$ \\
\hline AZA* & 54.88 & 0.9880 & 48.22 & 0.9878 & - & - & - & - & - & - & $50.17 \pm 4.17$ & $42.15 \pm 8.11$ & - & - & - \\
\hline Tacrine $* *$ & - & - & - & - & 76.2 & 0.9874 & 96.4 & 0.9424 & - & - & - & - & $47.18 \pm 8.37$ & $69.08 \pm 13.40$ & - \\
\hline Acarbose $* * *$ & - & - & - & - & - & - & - & - & 22.80 & - & - & - & - & - & $12.60 \pm 0.7$ \\
\hline
\end{tabular}

${ }^{*}$ AZA (acetazolamide) was used as a positive control for human carbonic anhydrase I and II isoforms (hCA I and II). ${ }^{* *}$ TAC (tacrine) was used as a positive control for acetylcholinesterase $(\mathrm{AChE})$ and butyrylcholinesterase (BChE) enzymes. ${ }^{* * *}$ Acarbose was used as a positive control for $\alpha$-glycosidase enzyme [40]. 


\section{Conclusions}

Consequently, in this study, a novel hydroxyethyl-substituted Ag-NHC complex 1 was synthesized and has been fully characterized by using FT-IR, ${ }^{1} \mathrm{H}$ NMR, ${ }^{13} \mathrm{C}$ NMR, and UV-Vis spectroscopy and elemental analysis techniques. As a result of all characterization data, the novel Ag-NHC complex 1 exhibited great compatibility with the proposed formulas. Single-crystal X-ray diffraction analysis displayed the T-shaped geometry for a three-coordinate silver atom. Bromide anions play a bridge role to connect the molecules and occur one-dimensional infinite chain along the b-axis. Ag-NHC complex 1 was found to be a good inhibitor for hCA I and hCA II isoenzymes, $\alpha$-glycosidase, AChE and BChE enzymes. This type of compound can be used for the development of novel antiglaucoma, antiepileptic, anticholinesterase, and anticancer drugs.

Author Contributions: Investigation, A.A., P.T., H.A.; writing-original draft preparation, D.B.C.; writing-review and editing, Y.G., İ.G. All authors have read and agreed to the published version of the manuscript.

Funding: This research received no external funding.

Acknowledgments: The authors thank the Inonu University Faculty of Science Department of Chemistry for the characterization of compounds and Inonu University Technology Center for the elemental analyses of the complex. The authors also acknowledge Dokuz Eylül University for the use of the Oxford Rigaku Xcalibur Eos Diffractometer (purchased under University Research Grant No: 2010.KB.FEN.13).

Conflicts of Interest: The authors declare no conflict of interest.

\section{References}

1. Asekunowo, P.O.; Haque, R.A. Counterion-induced modulation in biochemical properties of nitrile functionalized silver (I)-N-heterocyclic carbene complexes. J. Coord. Chem. 2014, 67, 3649-3663. [CrossRef]

2. Melaiye, A.; Simons, R.S.; Milsted, A.; Pingitore, F.; Wesdemiotis, C.; Tessier, C.A.; Youngs, W.J. Formation of water-soluble pincer Silver(I)-Carbene complexes: A novel antimicrobial agent. J. Med. Chem. 2004, 47, 973-977. [CrossRef] [PubMed]

3. Habib, A.; Iqbal, M.A.; Bhatti, H.N.; Kamal, A.; Kamal, S. Synthesis of alkyl/aryl linked binuclear Silver(I)-N-heterocyclic carbene complexes and evaluation of their antimicrobial, hemolytic and thrombolytic potential. Inorg. Chem. 2020, 111, 107670. [CrossRef]

4. Haque, R.A.; Iqbal, M.A.; Mohamad, F.; Razali, M.R. Antibacterial and DNA cleavage activity of carbonyl functionalized N-heterocyclic carbene-silver (I) and selenium compounds. J. Mol. Struct. 2018, 1155, 362-370. [CrossRef]

5. Alisir, S.H.; Sariboga, B.; Caglar, S.; Buyukgungor, O. Synthesis, characterization, photoluminescent properties and antimicrobial activities of two novel polymeric silver (I) complexes with diclofenac. J. Mol. Struct. 2017, 1130, 156-164. [CrossRef]

6. Yıldırım, I.; Aktas, A.; Barut Celepci, D.; Kırbag, S.; Kutlu, T.; Gok, Y.; Aygün, M. Synthesis, characterization, crystal structure, and antimicrobial studies of 2-morpholinoethylsubstituted benzimidazolium salts and their silver(I)-N-heterocyclic carbene complexes. Res. Chem. Intermed. 2017, 43, 6379-6393.

7. Aktas, A.; Keleştemur, U.; Gok, Y.; Balcıoglu, S.; Ates, B.; Aygun, M. 2-Morpholinoethyl-substituted N-heterocyclic carbene (NHC) precursors and their silver(I)NHC complexes: Synthesis, crystal structure and in vitro anticancer properties. J. Iran. Chem. Soc. 2018, 15, 131-139. [CrossRef]

8. Öfele, K. 1,3-Dimethyl-4-imidazolinyliden-(2)-pentacarbonylchrom ein neuer übergangsmetall carben komplex. J. Organomet. Chem. 1968, 12, 42-43. [CrossRef]

9. Wanzlick, H.W.; Schönherr, H.J. Direct synthesis of a mercury salt-carbene complex. Angew. Chem. 1968, 7, 141-142. [CrossRef]

10. Gok, Y.; Aktaş, A.; Erdoğan, H.; Sarı, Y. New 4-vinylbenzyl-substituted bis(NHC)-Pd(II) complexes: Synthesis, characterization and the catalytic activity in the direct arylation reaction. Inorg. Chim. Acta 2018, 471, 735-740. [CrossRef]

11. Erdogan, H.; Aktas, A.; Gok, Y.; Sar1, Y. N-Propylphthalimide-substituted bis-(NHC)PdX2 complexes: Synthesis, characterization and catalytic activity in direct arylation reactions. Transit. Met. Chem. 2018, 43, 31-37. [CrossRef] 
12. Aksu, K.; Ozgeriş, B.; Taslimi, P.; Naderi, A.; Gulcin, I.; Goksu, S. Antioxidant activity, acetylcholinesterase and carbonic anhydrase inhibitory properties of novel ureas derived from phenethylamines. Arch. Pharm. 2016, 349, 944-954. [CrossRef] [PubMed]

13. Altay, A.; Tohma, H.; Durmaz, L.; Taslimi, P.; Korkmaz, M.; Gulcin, I.; Koksal, E. Preliminary phytochemical analysis and evaluation of in vitro antioxidant, antiproliferative, antidiabetic and anticholinergics effects of endemic Gypsophila taxa from Turkey. J. Food Biochem. 2019, 43, e12908. [CrossRef] [PubMed]

14. Atmaca, U.; Yıldırım, A.; Taslimi, P.; Tuncel Çelik, S.; Gulcin, I.; Supuran, C.T.; Çelik, M. Intermolecular amination of allylic and benzylic alcohols leads to effective inhibitions of acetylcholinesterase enzyme and carbonic anhydrase I and II isoenzymes. J. Biochem. Mol. Toxicol. 2018, 32, e22173. [CrossRef] [PubMed]

15. Bayrak, C.; Taslimi, P.; Gulcin, I.; Menzek, A. The first synthesis of 4-phenylbutenone derivative bromophenols including natural products and their inhibition profiles for carbonic anhydrase, acetylcholinesterase and butyrylcholinesterase enzymes. Bioorg Chem. 2017, 72, 359-366. [CrossRef] [PubMed]

16. Bayrak, C.; Taslimi, P.; Kahraman, H.S.; Gulcin, I.; Menzek, A. The first synthesis, carbonic anhydrase inhibition and anticholinergic activities of some bromophenol derivatives with $\mathrm{S}$ including natural products. Bioorg. Chem. 2019, 85, 128-139. [CrossRef]

17. Ozmen Ozgun, D.; Yamali, C.; Gul, H.I.; Taslimi, P.; Gulcin, I.; Yanik, T.; Supuran, C.T. Inhibitory effects of isatin Mannich bases on carbonic anhydrases, acetylcholinesterase and butyrylcholinesterase. J. Enzyme Inhib. Med. Chem. 2016, 31, 1498-1501. [CrossRef]

18. Bicer, A.; Taslimi, P.; Yakal1, G.; Gulcin, I.; Gultekin, M.S.; Cin, G.T. Synthesis, characterization, crystal structure of novel bis-thiomethylcyclohexanone derivatives and their inhibitory properties against some metabolic enzymes. Bioorg. Chem. 2019, 82, 393-404. [CrossRef]

19. Burmaoglu, S.; Yilmaz, A.O.; Taslimi, P.; Algul, O.; Kılıç, D.; Gulcin, I. Synthesis and biological evaluation of phloroglucinol derivatives possessing $\alpha$-glycosidase, acetylcholinesterase, butyrylcholinesterase, carbonic anhydrase inhibitory activity. Arch. Pharm. 2018, 351, e1700314. [CrossRef]

20. Bursal, E.; Aras, A.; Kılıc, Ö.; Taslimi, P.; Gören, A.C.; Gulcin, I. Phytochemical content, antioxidant activity and enzyme inhibition effect of Salvia eriophora Boiss. \& Kotschy against acetylcholinesterase, $\alpha$-amylase, butyrylcholinesterase and $\alpha$-glycosidase enzymes. J. Food Biochem. 2019, 43, e12776.

21. Caglayan, C.; Demir, Y.; Kucukler, S.; Taslimi, P.; Kandemir, F.M.; Gulcin, I. The effects of hesperidin on sodium arsenite-induced different organ toxicity in rats on metabolic enzymes as antidiabetic and anticholinergics potentials: A biochemical approach. J. Food Biochem. 2019, 43, e12720. [CrossRef]

22. Caglayan, C.; Taslimi, P.; Demir, Y.; Kucukler, S.; Kandemir, M.F.; Gulcin, I. The effects of zingerone against vancomycin-induced lung, liver, kidney and testis toxicity in rats: The behavior of some metabolic enzymes. J. Biochem. Mol. Toxicol. 2019, 33, e22381. [CrossRef]

23. Aktas, A.; Taslimi, P.; Gok, Y.; Gulcin, I. Novel NHC precursors: Synthesis, characterization, and carbonic anhydrase and acetylcholinesterase inhibitory properties. Arch. Pharm. 2017, 350, e1700045. [CrossRef] [PubMed]

24. Erdemir, F.; Barut Celepci, D.; Aktas, A.; Taslimi, P.; Gok, Y.; Karabıyık, H.; Gulcin, I. 2-Hydroxyethyl substituted NHC precursors: Synthesis, characterization, crystal structure and carbonic anhydrase, a-glycosidase, butyrylcholinesterase, and acetylcholinesterase inhibitory properties. J. Mol. Struct. 2018, 1155, 797-806. [CrossRef]

25. Türker, F.; Barut Celepci, D.; Aktas, A.; Taslimi, P.; Gok, Y.; Aygün, M.; Gulcin, I. Meta-cyanobenzyl substituted benzimidazolium salts: Synthesis, characterization, crystal structure and carbonic anhydrase, $\alpha$-glycosidase, butyrylcholinesterase, and acetylcholinesterase inhibitory properties. Arch. Pharm. 2018, 351, 1800029.

26. Behcet, A.; Caglilar, T.; Barut, C.D.; Aktas, A.; Taslimi, P.; Gok, Y.; Aygun, M.; Kaya, R.; Gulcin, I. Synthesis, characterization and crystal structure of 2-(4-hydroxyphenyl)ethyl and 2-(4-nitrophenyl)ethyl Substituted Benzimidazole Bromide Salts: Their inhibitory properties against carbonic anhydrase and acetylcholinesterase. J. Mol. Struct. 2018, 1170, 160-169. [CrossRef]

27. Aktas, A.; Barut Celepci, D.; Kaya, R.; Taslimi, P.; Gok, Y.; Aygun, M.; Gulcin, I. Novel morpholine liganded Pd-based N-heterocyclic carbene complexes: Synthesis, characterization, crystal structure, antidiabetic and anticholinergic properties. Polyhedron 2019, 159, 345-354. [CrossRef]

28. Aktas, A.; Noma, S.A.A.; Barut Celepci, D.; Erdemir, F.; Gok, Y.; Ates, B. New 2-hydroxyethyl substituted n-heterocyclic carbene precursors: Synthesis, characterization, crystal structure and inhibitory properties against carbonic anhydrase and xanthine oxidase. J. Mol. Struct. 2019, 1184, 487-494. [CrossRef] 
29. Erdemir, F.; Barut Celepci, D.; Aktas, A.; Gok, Y.; Kaya, R.; Taslimi, P.; Demir, Y.; Gulcin, I. Novel 2-aminopyridine liganded $\mathrm{Pd}(\mathrm{II}) \mathrm{N}$-heterocyclic carbene complexes: Synthesis, characterization, crystal structure and bioactivity properties. Bioorg. Chem. 2019, 91, 103134. [CrossRef]

30. Bal, S.; Aktas, A.; Kaya, R.; Gok, Y.; Karaman, M.; Taslimi, P.; Gulcin, I. Novel 2-methylimidazolium salts: Synthesis, characterization, molecular docking, and carbonic anhydrase and acetylcholinesterase inhibitory properties. Bioorg. Chem. 2020, 94, 103468. [CrossRef]

31. Aktas, A.; Gok, Y. N-Propylphthalimide-substituted Silver(I) N-heterocyclic carbene complexes and Ruthenium(II) N-heterocyclic carbene complexes: Synthesis and transfer hydrogenation of ketones. Trans. Met. Chem. 2014, 39, 925-931. [CrossRef]

32. Verpoorte, J.A.; Mehta, S.Ç.; Edsall, J.T. Esterase activities of human carbonic anhydrases B and C. J. Biol. Chem. 1967, 242, 4221-4229. [PubMed]

33. Hisar, O.; Beydemir, Ş.; Gulcin, I.; Kufrevioglu, O.I.; Supuran, C.T. Effect of low molecular weight plasma inhibitors of rainbow trout (Oncorhyncytes mykiss) on human erythrocytes carbonic anhydrase-II isozyme activity in vitro and rat erythrocytes in vivo. J. Enzyme Inhib. Med. Chem. 2005, 20, 35-39. [CrossRef] [PubMed]

34. Caglayan, C.; Taslimi, P.; Türk, C.; Kandemir, F.M.; Demir, Y.; Gulcin, I. Purification and characterization of the carbonic anhydrase enzyme from horse mackerel (Trachurus trachurus) muscle and the impact of some metal ions and pesticides on enzyme activity. Comp. Biochem. Physiol. 2019, 226, 108605. [CrossRef]

35. Ozbey, F.; Taslimi, P.; Gulcin, I.; Maras, A.; Goksu, S.; Supuran, C.T. Synthesis, acetylcholinesterase, butyrilcholinesterase, carbonic anhydrase inhibitory and metal chelating properties of some novel diaryl ether. J. Enzyme Inhib. Med. Chem. 2016, 31, 79-85. [CrossRef]

36. Oztaskın, N.; Taslimi, P.; Maras, A.; Goksu, S.; Gulcin, I. Novel antioxidant bromophenols with acetylcholinesterase, butyrylcholinesterase and carbonic anhydrase inhibitory actions. Bioorg. Chem. 2017, 74, 104-114.

37. Ellman, G.L.; Courtney, K.D.; Andres, V.; Featherston, R.M. A new and rapid colorimetric determination of acetylcholinesterase activity. Biochem. Pharmacol. 1961, 7, 88-95. [CrossRef]

38. Cetin, A.; Turkan, F.; Taslimi, P.; Gulcin, I. Synthesis and characterization of novel substituted thiophene derivatives and discovery of their carbonic anhydrase and acetylcholinesterase inhibition effects. J. Biochem. Mol. Toxicol. 2019, 33, e22261. [CrossRef]

39. Daryadel, S.; Atmaca, U.; Taslimi, P.; Gulcin, I.; Celik, M. Novel sulfamate derivatives of menthol: Synthesis, characterization, and cholinesterases and carbonic anhydrase enzymes inhibition properties. Arch. Pharm. 2018, 351, 1800209. [CrossRef]

40. Tao, Y.; Zhang, Y.; Cheng, Y.; Wang, Y. Rapid screening and identification of $\alpha$-glucosidase inhibitors from mulberry leaves using enzyme-immobilized magnetic beads coupled with HPLC/MS and NMR. Biomed. Chromatogr. 2013, 27, 148-155. [CrossRef]

41. Demir, Y.; Durmaz, L.; Taslimi, P.; Gulcin, I. Anti-diabetic properties of dietary phenolic compounds: Inhibition effects on $\alpha$-amylase, aldose reductase and $\alpha$-glycosidase. Biotechnol. Appl. Biochem. 2019, 66, 781-786. [CrossRef] [PubMed]

42. Demir, Y.; Taslimi, P.; Ozaslan, M.S.; Oztaskin, N.; Cetinkaya, Y.; Gulcin, I.; Beydemir, S..; Goksu, S. Antidiabetic potential: In vitro inhibition effects of bromophenol and diarylmethanones derivatives on metabolic enzymes. Arch. Pharm. 2018, 351, 1800263. [CrossRef] [PubMed]

43. Rigaku Corporation. CrysAlis(Pro) Software System; Version 1.171.38.43; Rigaku Corporation: Oxford, UK, 2015.

44. Clark, R.C.; Reid, J.S. The analytical calculation of absorption in multifaceted crystals. Acta Crystallogr. A Found. Crystallog. 1995, A51, 887-897. [CrossRef]

45. Dolomanov, O.V.; Bourhis, L.J.; Gildea, R.J.; Howard, J.A.K.; Puschmann, H. OLEX2: A complete structure solution, refinement and analysis program. J. Appl. Cryst. 2009, 42, 339-341. [CrossRef]

46. Sheldrick, G.M. SHELXT-integrated space-group and crystal-structure determination. Acta Crystallogr. A Found. Crystallogr. 2015, A71,3-8. [CrossRef] [PubMed]

47. Sheldrick, G.M. Crystal structure refinement with SHELXL. Acta Crystallogr. C Struct. Chem. 2015, C71, 3-8. [CrossRef] [PubMed] 
48. Aktas, A.; Barut Celepci, D.; Gok, Y. Novel 2-hydroxyethyl substituted N-coordinate-Pd(II)(NHC) and bis(NHC)Pd(II) complexes: Synthesis, characterization and the catalytic activity in the direct arylation reaction. J. Chem. Sci. 2019, 131, 78. [CrossRef]

49. Aktas, A. A new palladium complex containing mixture of carbene and phosphine ligands: Synthesis, crystal structures, spectral FTIR, NMR and UV-Vis researched. Chin. J. Struct. Chem. 2019, 38, 1664-1672.

50. Ahmad, S.; Georgieva, I.; Hanif, M.; Monim-ul-Mehboob, M.; Munir, S.; Sohail, A.; Isab, A.A. Periodic DFT modeling and vibrational analysis of silver(I) cyanide complexes of thioureas. J. Mol. Model. 2019, $25,90$.

51. Kılıc, A.; Tas, E.; Gumgum, B.; Yılmaz, I. Synthesis, Spectroscopic and electrochemical investigations of two vic-dioximes and their mononuclear $\mathrm{Ni}(\mathrm{II}), \mathrm{Cu}(\mathrm{II})$ and $\mathrm{Co}(\mathrm{II})$ metal complexes containing morpholine group. Chin. J. Chem. 2006, 24, 1599-16004.

52. Sacconi, L.; Ciampolini, M.; Maffio, F.; Cavasino, F.P. Studies in coordination chemistry. IX.1 investigation of the stereochemistry of some complex compounds of cobalt(II) with N-substituted salicylaldimines. J. Am. Chem. Soc. 1962, 84, 3245-3248. [CrossRef]

53. Aktas, A.; Barut Celepci, D.; Gök, Y. Synthesis, crystal structures, spectral FT-IR, NMR and UV-Vis investigations and Hirshfeld surface analysis of two new 2-hydroxyethyl substituted N-heterocyclic carbene (NHC) precursors. J. Chin. Chem. Soc. 2019, 66, 1389-1396. [CrossRef]

54. Hirtenlehner, C.; Krims, C.; Hölbling, J.; List, M.; Zabel, M.; Fleck, M.; Berger, R.J.F.; Schoefbergera, W.; Monkowius, U. Syntheses, crystal structures, reactivity, and photochemistry of gold(III) bromides bearing N-heterocyclic carbenes. Dalton Trans. 2011, 40, 9899-9910. [CrossRef] [PubMed]

55. Saif, M.J.; Flowe, K.R. A general method for the preparation of N-heterocyclic carbene-Silver(I) complexes in water. Trans. Met. Chem. 2013, 38, 113-118. [CrossRef]

56. Balaydin, H.T.; Gulcin, I.; Menzek, A.; Goksu, S.; Sahin, E. Synthesis and antioxidant properties of diphenylmethane derivative bromophenols including a natural product. J. Enzyme Inhib. Med. Chem. 2010, 25, 685-695. [CrossRef]

57. Nar, M.; Cetinkaya, Y.; Gulcin, I.; Menzek, A. (3,4-Dihydroxyphenyl)(2,3,4-trihydroxyphenyl)methanone and its derivatives as carbonic anhydrase isoenzymes inhibitors. J. Enzyme Inhib. Med. Chem. 2013, 28, 402-406. [CrossRef]

58. Ekiz, M.; Tutar, A.; Okten, S.; Butun, B.; Kocyigit, U.M.; Taslimi, P.; Topcu, G. Synthesis, characterization and SAR of arylated indenoquinolinebased cholinesterase and carbonic anhydrase inhibitors. Arch. Pharm. 2018, 351, 1800167. [CrossRef]

59. Garibov, E.; Taslimi, P.; Sujayev, A.; Bingol, Z.; Cetinkaya, S.; Gulcin, I.; Beydemir, S.; Farzaliyev, V.; Alwasel, S.H.; Supuran, C.T. Synthesis of 4,5-disubstituted-2-thioxo-1,2,3,4-tetrahydropyrimidines and investigation of their acetylcholinesterase, butyrylcholinesterase, carbonic anhydrase I/II inhibitory and antioxidant activities. J. Enzyme Inhib. Med. Chem. 2016, 31, 1-9. [CrossRef]

60. Gocer, H.; Topal, F.; Topal, M.; Kucuk, M.; Teke, D.; Gulcin, I.; Alwasel, S.H.; Supuran, C.T. Acetylcholinesterase and carbonic anhydrase isoenzymes I and II inhibition profiles of taxifolin. J. Enzyme Inhib. Med. Chem. 2016, 31, 441-447. [CrossRef]

61. Genc Bilgicli, H.; Kestane, A.; Taslimi, P.; Karabay, O.; Bytyqi-Damoni, A.; Zengin, M.; Gulcin, I. Novel eugenol bearing oxypropanolamines: Synthesis, characterization, antibacterial, antidiabetic, and anticholinergic potentials. Bioorg. Chem. 2019, 88, 102931. [CrossRef]

62. Cetin Cakmak, K.; Gulcin, I. Anticholinergic and antioxidant activities of usnic acid-An activity-structure insight. Toxicol. Rep. 2019, 6, 1273-1280. [CrossRef] [PubMed]

63. Polat Kose, L.; Gulcin, I.; Goren, A.C.; Namiesnik, J.; Martinez-Ayala, A.L.; Gorinstein, S. LC-MS/MS analysis, antioxidant and anticholinergic properties of galanga (Alpinia officinarum Hance) rhizomes. Ind. Crops Prod. 2015, 74, 712-721. [CrossRef]

64. Gulcin, I.; Tel, A.Z.; Goren, A.C.; Taslimi, P.; Alwasel, S. Sage (Salvia pilifera): Determination its polyphenol contents, anticholinergic, antidiabetic and antioxidant activities. J. Food Meas. Charact. 2019, 13, $2062-2074$. [CrossRef]

65. Gulcin, I.; Taslimi, P.; Aygün, A.; Sadeghian, N.; Bastem, E.; Kufrevioglu, O.I.; Turkan, F.; Şen, F. Antidiabetic and antiparasitic potentials: Inhibition effects of some natural antioxidant compounds on $\alpha$-glycosidase, $\alpha$-amylase and human glutathione S-transferase enzymes. Int. J. Biol. Macromol. 2018, 119, 741-746. [CrossRef] 
66. Bytyqi-Damoni, A.; Kestane, A.; Taslimi, P.; Tüzün, B.; Zengin, M.; Genç Bilgicli, H.; Gulcin, I. Novel carvacrol based new oxypropanolamine derivatives: Design, synthesis, characterization, biological evaluation, and molecular docking studies. J. Mol. Struct. 2020, 1202, 127297. [CrossRef]

67. Biçer, A.; Kaya, R.; Yakali, G.; Gultekin, M.S.; Turgut Cin, G.; Gulcin, I. Synthesis of novel $\beta$-amino carbonyl derivatives and their inhibition effects on some metabolic enzymes. J. Mol. Struct. 2020, 1204, 127453.

68. Eruygur, N.; Atas, M.; Tekin, M.; Taslimi, P.; Kocyigit, U.M.; Gulcin, I. In vitro antioxidant, antimicrobial, anticholinesterase and antidiabetic activities of Turkish endemic Achillea cucullata (Asteraceae) from ethanol extract. S. Afr. J. Bot. 2019, 120, 141-145. [CrossRef]

69. Oztaskin, N.; Kaya, R.; Maras, A.; Sahin, E.; Gulcin, I.; Goksu, S. Synthesis and characterization of novel bromophenols: Determination of their anticholinergic, antidiabetic and antioxidant activities. Bioorg. Chem. 2019, 87, 91-102. [CrossRef]

(C) 2020 by the authors. Licensee MDPI, Basel, Switzerland. This article is an open access article distributed under the terms and conditions of the Creative Commons Attribution (CC BY) license (http://creativecommons.org/licenses/by/4.0/). 